\title{
Impact of Increasing Pollution Rates on Public Health in Kazakhstan
}

\author{
Kalimova Ainara, Dong Bin, Davaasambuu Ulzii-orhsikh.
}

Tongji University, College of Environmental Science and Engineering, Department of Environmental Science

Surface water research division of the Information and Research Institute of Meteorology, Hydrology and Environment, of

Kazakhstan

DOI: 10.29322/IJSRP.10.03.2020.p9941

http://dx.doi.org/10.29322/IJSRP.10.03.2020.p9941

\begin{abstract}
The rising dilemma in Kazakhstan and its vicinity areas are regarding pollutant factors. The pollution burst has severed in the Caspian Sea and Aral Sea regions. The pollution has triggered deeply rooted effects like climate change, sociodemographic changes and economic changes. The Kazakhstan people has become susceptible to several illness related to heart, kidney, liver and other deformities. The women and infants are at the major risk of getting such ailment. This study has included secondary data to accomplish understanding of ecological changes in Kazakhstan. Both anthropologic and natural causes are underlying the stimulated changes in nature and natural resources. MajorBiodiversity degradation is the prime concern in this region.
\end{abstract}

Index terms- Climate change, hydrocarbons, desiccation, poisonous pesticide, Kazakhstan

\section{INTRODUCTION}

Exposure of the population to significant ambient nature of Kazakhstan has caused severe imbalance in ecological factors. There are several factors that can cause ecological degradation in Kazakhstan areas especially at Caspian Sea and Aral Sea areas. The foremost dilemma among them is pollution due to oil extraction from mining and industrial activities. Transportation accidents and damage also pose several negative consequences on the marine population and adjacent biodiversity. The important ecological degradation in the Caspian and Aral areas due to anthropogenic or nature caused petroleum hydrocarbons has been demonstrated in threadbare. Health consequences and ecological consequences due to such drastic conditions have been discussed in this study.

\section{DATA COLLECTION AND IDENTIFICATION OF RESEARCH}

The research study has applied analytical and documentary methods for obtaining relevant information about the ecological issues faced in Kazakhstan. For this purpose, research journals, government reports and ecosystem reservation information are assessed and analysed to develop a strategic understanding about potential threats of the ecosystem in Kazakhstan. The secondary analysis involved evaluation of 15 sources including articles, reports and government data that are collected from educational databases such as ProQuest, SCOPUS and Google scholar, whereas the governmental repositories are scoured to access the reports provided by Kazakhstan government.

These articles critically highlighted the environmental issues present in the marine systems and land ecosystem, while highlighting the exploitation of petroleum extraction, oil gas exposure and other human activities. Strategy [16] commented that social development schemes, actions and implemented systems are also evaluated to support the progress environment protection activities with the concern of saving the present biodiversity of marine bodies in Kazakhstan.

Fig1: PRISMA framework

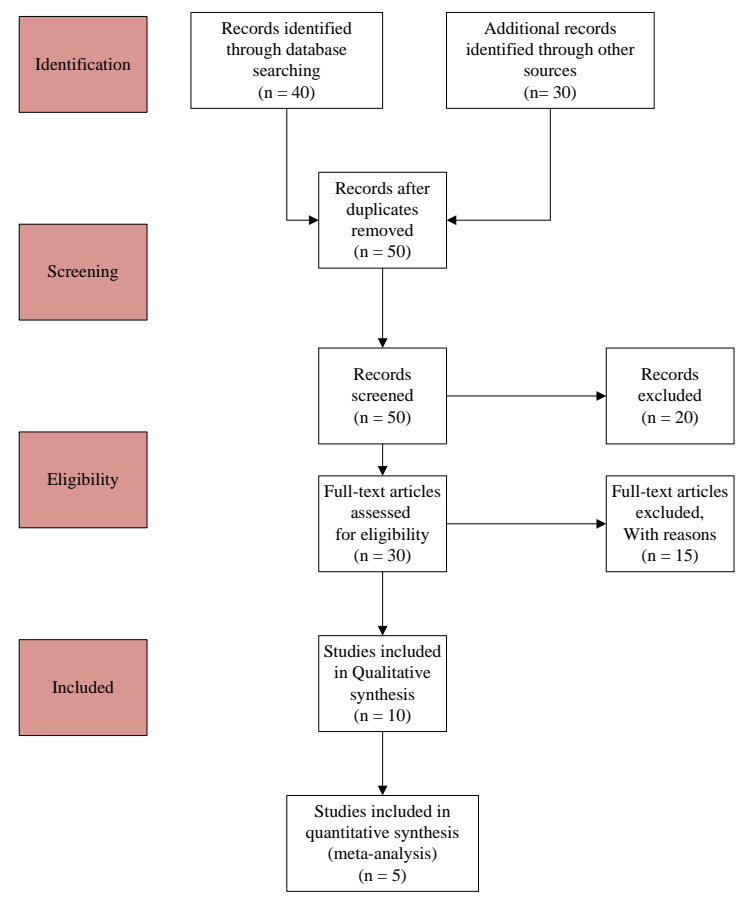

(Source: Created by author) 


\section{FINDINGS}

\subsection{Hydrobiology of Caspian Sea}

Being the largest lake in Kazakhstan, it exhibits a large diversity of flora and fauna. Considering the phytoplankton, macro-benthos, zooplanktons and Ctenophore along with physicochemical parameters, Caspian Sea demonstrates high variation in the ecology. Nature [15] viewed that diversity in biotopes, abiotic and biotic conditions of Caspian Sea are highly vulnerable to the increasing changes in climate, human activities that endanger the ecological balance in this enclosed water body. The current environmental situation in Caspian Sea exhibits the loss of biodiversity due to the progress of Dead Zone creation and a drastic decline in natural ecological components. For instance, the trend of sturgeon catch is decreased by $37 \%$ with a mass loss of diversity of water bodies.

\section{Fig 2: Caspian Sea}

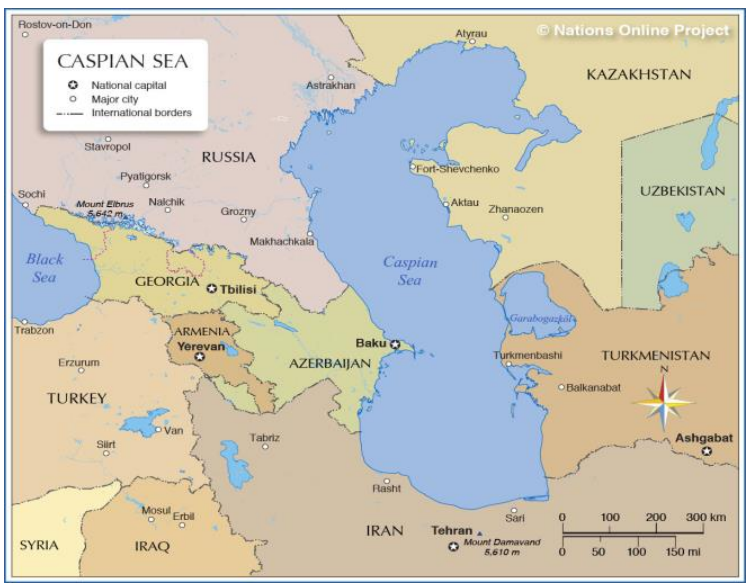

(Source: naturvernforbundet.no, 2020)

The natural resources of Caspian Sea include minerals, biological resources, balneological and agro-climatic components along with recreational elements. In addition to the valuable biological resources, oil resources and hydrocarbons are major elemental sources for Caspian Sea, which supports the ecological balance considering minerals and physical components of nature. However, Onyusheva [11] mentioned that the current environmental situation is under threat due to population burst and destruction of natural resources. Considering the river flow, wastewater disposal from onshore industries and municipalities, oil extraction and increase in sea level. Edu [3] showed that extensive air, water and land pollution created from intensive oil and gas development in Caspian region that have exhausted the natural resources and disturbed the ecosystem with a loss of $99 \%$ of its spawning ground and $80 \%$ of Caspian sturgeon.

The reasons behind the loss of biodiversity in Caspian Sea indicate obsolete production technology for oil production and extraction, inefficient treatment equipment, lack of technology to balance the use of renewable and non-renewable resources and the low quality of fuel. Krupa[6] stated that the experimental pilot plant "Aktau-1" for controlling and improving oil extraction failed due to technical difficulties that increased technological needs and support for operating practices with the concern of environmental balance. The concern of increasing loss of biodiversity in Caspian Sea and severe implications of environmental issues on daily life, the water areas are reserved and protected in three National parks such as Astrakhan, Gizil-Agach and Khazar that protected diverse flora and fauna in the northern part and southeast coast.

Fig 3: Caspian Sea relief borders
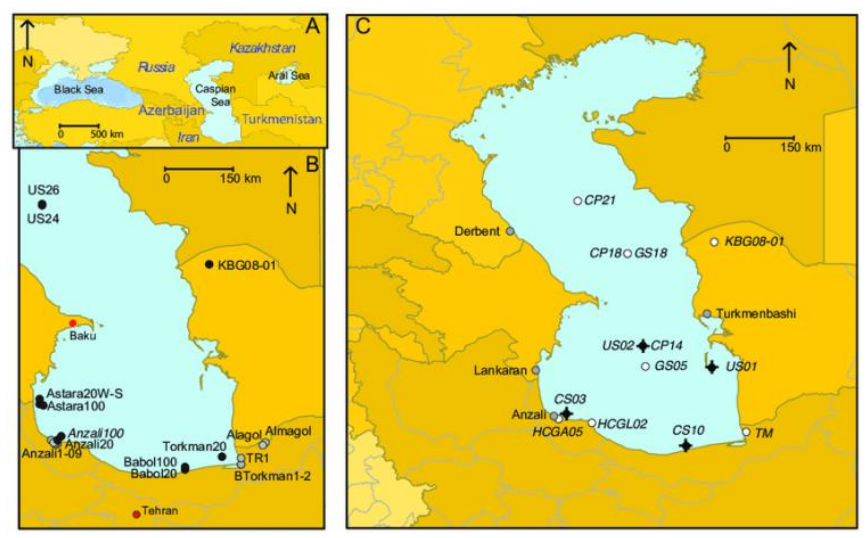

(Source: naturvernforbundet.no, 2020)

Caspian Sea region includes 1800-2000 diverse species which are threatened with oil and gas pollution, specifically at the shore of Absheron Peninsula. Moreover, Caspian Environment Program (CEP) reported sewage (169 million cubic meter of raw sewage and 240 million cubic meter of treated sewage) disposal in Caspian sea has negatively affected the water bodies by increasing biological and dissolved oxygen demand along with the creation of ecological condition for algal bloom and adversities such as high alkalinity for the growth of microbes in water bodies. Issanova[9] showed that National Caspian Action Plan (NCAP) and Ecoregion Conservation Plan for the Caucasus (ECPC) have been implemented to ensure the conservation of ecological balance in this region.

\subsection{Marine environmental pollution due to petroleum hydrocarbons}

Petroleum contamination in terrestrial and aquatic ecosystems is one of the leading conversions as they are effective in destroying the natural ecosystem and increase the potential of increasing risks of disasters. Karbetova[23] commented that typical toxicants in destroying the Caspian Sea ecosystem is categorised as the hydrocarbons with specific reference to petroleum. The issues with oil extraction, treatment of water bodies and waste disposal are effective in increasing the potential of damaging the ecosystem there. Other water bodies in Kazakhstan are chiefly polluted by agricultural and industrial runoff and in some cases it is radioactivity that destroys the natural habitation of water bodies' ion including freshwater and marine water of Kazakhstan. 
Fig 4: Marine Population Indices

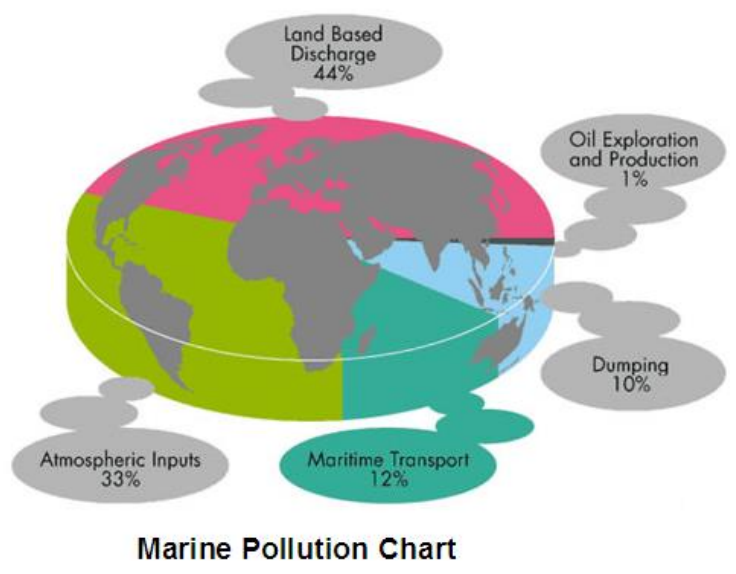

(Source: columbia.edu, 2020)

The marine bodies of Kazakhstan mainly encompass the Aral Sea, Lake Balkhash, Caspian Sea and Dead Sea. Facts [4] opined marine environment protection is established in Kazakhstan to ensure the maintenance of marine ecology of these biologically diverse spots in the country. Limited technology in oil extraction in these regions has resulted in increased pollution with hydrocarbons, surfactants, and heavy metals. Igaliyeva [18] showed that chloral organic pesticides and phenol. Primarily, petroleum hydrocarbons are responsible for changing the morphological, physiological and biochemical structure of organisms and physical environment, which are irreversible and cause chronic pathological effects. Khalilova [13] stated, in the Northern region of Caspian Sea oil pollution is recorded to be ranging from 1 to $6 \mathrm{MPC}$, which can be reasoned with oil outflow from poor oil extraction processes from then offshore wells of Caspian Sea.

Oil spill and extraction processes from marine bodies are harmful to the ecosystem affecting the marine lives adversely. The chemical constituents of petroleum and exposure of organs can increase toxicity and poison the fauna and flora. In Kazakhstan, the marine water bodies are primarily contaminated with oil spills, illegal discharge of ballast, discharge of fish processing waste and bilge water. Moreover, Amanova[7] stated that petroleum by-products are similar in the effects of affecting the biodiversity of Caspian Sea, Aral Sea and other marine bodies. Kadyrbergenova [1] opined regional government corporations are initiated to ensure the preservation of marine bodies in Kazakhstan in controlling the pool extraction in a regulated manner and monitoring the treatment processes, which also impact the economic development and ecosystem management.

\subsection{Nature-society linkage in the vicinity of Aral Sea}

The Aral Sea has stranded the border by separating northwestern Uzbekistan and Western Kazakhstan. In order to understand the pollution and its consequences, it is crucial to explore the transformation in the Aral Sea population. In the 1960s, the arrival of Soviet Union was the root behind the depletion of the Aral Sea water level. Bennett [12] stated the rerouting of rivers from respective sea due to execution of agricultural projects had reduced the incoming of water. Cotton monoculture imposed by Soviet Union population diversified almost $100 \%$ of the waters of Darya, Amu and Syr Rivers before meeting the Aral Sea. Such drastic action has resulted in evaporation of water and given the depiction of polluted swathe.

The population of Kazakhstan around the Aral Sea areas rose exhilaratingly. Bayandinova [19] opined the number raised from 13.8 million to 33.2 million people enforcing increase in 2.0 to 5.1 million in Kazakhstan as well. After two consecutive decades of eventual rise in population, the mean growth rate has been diminished in the basin areas of the Aral Sea. Due to an increase in population, the demand for natural gas and water has also escalated rapidly. Issanova [10] stated, in Kazakhstan, the water requirement of recent years has counted to be 1943 $\mathrm{m}^{3} /$ per person/annually. The water supply is significantly utilised in Municipal economy $\left(3.1 \mathrm{Km}^{3} /\right.$ year), power generation and industrial purposes $\left(8.3 \mathrm{Km}^{3} /\right.$ year), agriculture $\left(0.86 \mathrm{Km}^{3} /\right.$ year $)$, fisheries $\left(2.0 \mathrm{Km}^{3} /\right.$ year $)$ and irrigated farming $\left(114.0 \mathrm{Km}^{3} /\right.$ year $)$.

\section{Fig5: Water requisite in Aral Sea basin areas}

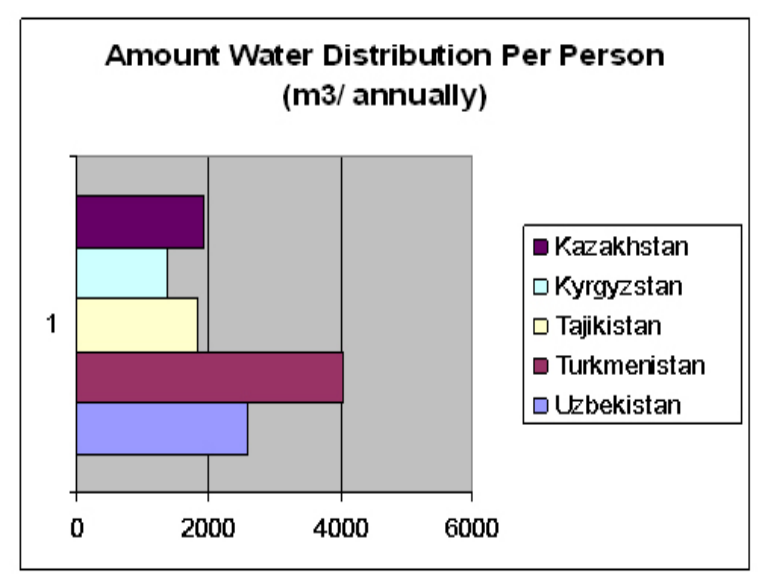

(Source: columbia.edu, 2020)

There is an intense demand for groundwater in the basin of the Aral Sea as it diversifies the load on the available water resources. The groundwater is reserved in the Amudaraya river surroundings and Aral region. The sea is being depleted largely and groundwater is the alternative source for the habitant people. The groundwater and river water are also utilised in the irrigated fields. Scientists have discovered that there is a seasonal alteration in the ground water quality. The oil pollutants tend to ooze in the groundwater and river water to destroy the drinkable and usable water resources. As per Mukhtarova [14], the rapid changes that have been observed due to higher degree of pollution are water and food shortages, changes in weather conditions. The temperature level rise has caused long lasting and frequent droughts in the Aral Sea belt regions. Intensive usage of water is primarily for land subsidence and vegetation purposes. Arystambekova [5] opines that, the salinity of Aral Sea water has been raised significantly and accounted to be almost $10 \mathrm{~g} / \mathrm{l}$. significant loss of water has caused Aral Sea desiccation and drop in sea water level up to 23 meter. 
ISSN 2250-3153

\subsection{Ecological imbalance in trans-boundary river basins adjacent to Aral Sea}

Climatic conditions of Aral Sea adjacent areas are also having aversive consequences due to evaporation of Aral Sea. The previous climate regulating Aral Sea has changed to offer colder and longer winters and shorter, dried summers. Precipitation level has reduced by 10 factors, humidity by $10 \%$. Winter temperature has shown to decrease by almost +2 to $3^{\circ} \mathrm{C}$ and the similar degree rises in summer. Report [20] showed that changes in climatic conditions have halved the Pasteur ground productions. Another aggravating factor for pollution is the position of highways near the Aral Sea. Issanova [8] stated the higher air current from west to east region spreads the aerosol particles in the upper atmospheric layer. Penguins of Antarctic regions were also found to be contaminated with aerosols generated in the Aral Sea beds. Karimova [2] entails, Aral dust is being carried away to the far fields of Belorussia, Norway forests and Greenland glaciers as well. Economic disaster also arose due to the collapse of the fishery business. The rate of unemployment has risen to 60,000 as they were connected with the Aral Sea for living.

\section{Fig6: Graphical representation of Aral Sea shrinking}

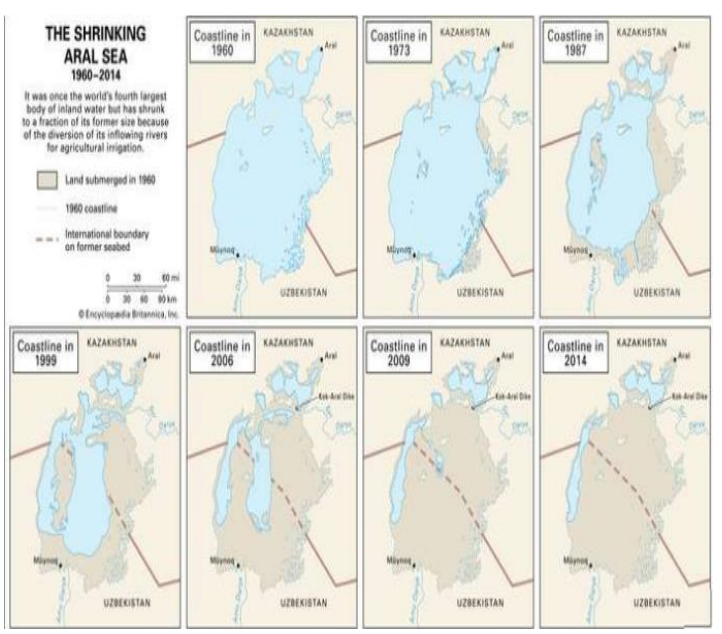

(Source: naturvernforbundet.no, 2020)

Aral Sea desiccation has put lethal consequences on mountain glacier degradation of Himalayas, Altais and Tien Shan. Igaliyeva [17] demonstrated, the rivers such as Amudarya, Syrdarya are fed through these glaciers and hence they are also being shrieked day by day. Glaciers are being melted due to an increase in toxic dust causing precipitation and mineralisation of glaciers. Severe threat has been imposed as Central Asia mountain glaciers are the prime source of atmospheric moisture and fresh water. Continuation of such sedimentation process will cause losing the efficacy of mountains to condense moisture. The river drainage will further decrease to cease due to the dramatic effect of sedimentation. The marine fishes were also contaminated with highly poisonous pesticides found in the Aral Rivers.

\subsection{Ecological and health consequences of Aral Sea crisis}

As per the reports of professionals of International medical health, the quality of life and health standards in the vicinity of Aral Sea is profoundly deteriorating and poor in nature. It was also found that, there is a direct association between the ecological devastation and Aral Sea crisis. Further research suggests that, the prime cause behind such population degradation is enhanced mineralization and salinity of water supplies. Increase in ailment among the adolescents of this region is directly linked to the ecological health declination. The rate of infant mortality has reached up to 100 in every 1000 live births. The maternity deaths have risen to 120 women in every 10,000 births. Issanova [8] stated the increased amount of parasites, pesticides in air and dust storms has created such a dilemma. Ecological, socio-economic factors and significant breakdown in health care infrastructure is the reason behind poor health and Aral Sea sufferings. The ailments that are most common in these areas are liver disease, kidney deformation, tuberculosis and higher rates of anaemia.

\section{Fig 7: Population density of Kyzyl-Orda area}

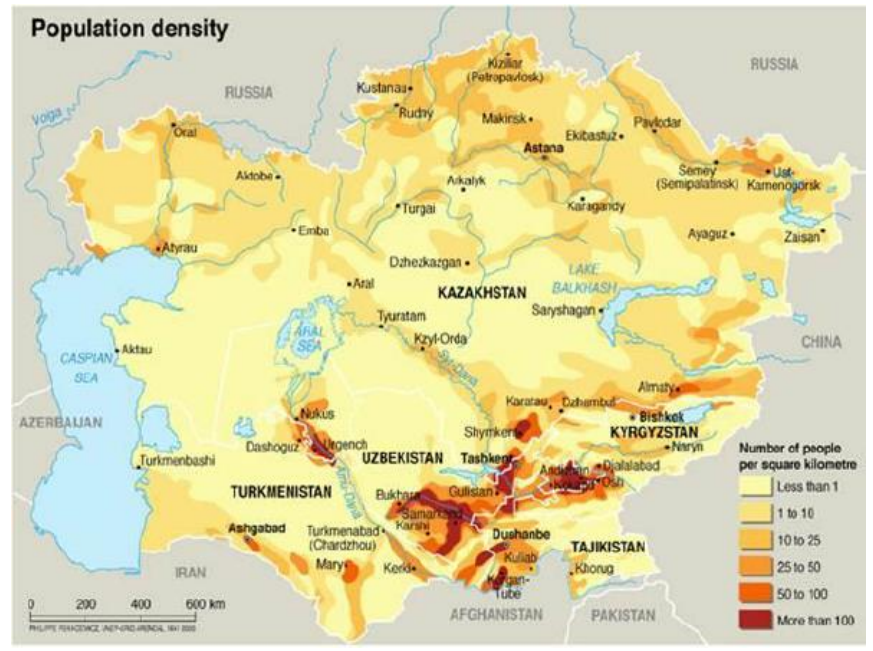

(Source: Report, 2020)

Average life expectancy of the Kyzyl-Orda area in Kazakhstan has been observed to decline up to 51 years from 64 years. Infants and women are mostly vulnerable to such diseases. $99 \%$ of pregnant females, $91 \%$ of non-pregnant females and $87 \%$ of teenagers suffer from anaemia. Females of Kazakhstan are suffering from reproductive pathologies such as birth complications, miscarriages and infertility for above 20 years. Abdukarimova [21] stated, pregnant women found to have excess levels of organochlorine pesticides such as pp-DDT, ppDDE, HCE and HCB in their plasma. Significant changes in fatal development and reproduction. In addition to that, there are increased risk of soft tissue cancers, neurobehavioral changes, dermatological changes and liver function impairment. People are also susceptible to endocrine malfunctioning and immune-suppression. Respective pollution from the natural resources found in karakalpakstan has caused chronic exposure of chemicals for a longer period of time. The underlying causes that have been identified are imbalance of health nutrients such as iodine deficiency, higher water mineralisation and pesticides. The social and medical factors are also associating elements behind this disaster.

Fig 8: Political, economic and health consequences 


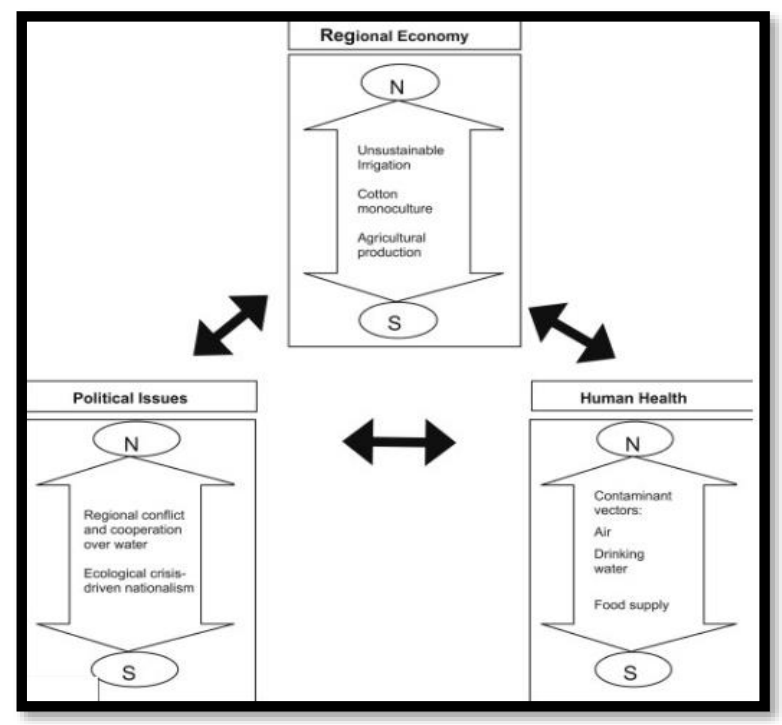

(Source: Report, 2020)

The quality of water deteriorated from the previous 40 to 45 years due to mineral increase in the sea water. Both the water supplies and soil have been contaminated with almost 150,000 tons of hazardous chemicals since the previous 10 years. Most of the fauna and flora under sea water has been destroyed because of drastic alteration in water quality. Abdukarimova [22] opines both the mining industry and agro industry are responsible for the subsequent pollution in water, air and soil of Kazakhstan. The groundwater is severely contaminated with minerals and salts. As per WHO (World Health Organisation), the standardised TDS (Total dissolved salts) in water is $1.5 \mathrm{~g} / \mathrm{l}$ which is safe for drinking and other utilisation. In the case of Kazakhstan areas, the ground water quality reflects a TDS of 4$6 \mathrm{~g} / \mathrm{l}$. Cotton monoculture in the adjacent areas is the primary reason behind agricultural soils and enhanced salinity.

\section{CONCLUSION}

There are several factors ruling around the degradation ecology of Kazakhstan and the adjacent areas. Two major factors that have been discussed in this study are the desiccation of the Aral Sea and petroleum extraction from Caspian Sea. From the analysis, it can be concluded that anthropogenic causes have ruptured the harmony of nature. The higher amount of petroleum extraction and Soviet Union monoculture has destroyed the balance of nature and climate. The social, demographic, economic, environmental conditions have been shattered due to the wrath of nature. Effective support from the governmental and non-governmental bodies is required along with public awareness to make a positive step towards repletion of nature and natural sources.

\section{ACKNOWLEDGEMENT}

The writers of this article would like to forward their gratitude to the reviewers and the scholarly authors for their contributions and aid in this paper.

\section{REFERENCES}

[1] A. Kadyrbergenova, S. Yegemberdiyeva and K. Orazbayeva, "FORMATION OF A PETROCHEMICAL CLUSTER AND THE CREATION OF AN INTEGRATED PETROCHEMICAL COMPLEX IN KAZAKHSTAN," $C B U$ International Conference Proceedings ..., vol. 5, pp. 211-217, 2017.

Available: https://search.proquest.com/docview/1976391778?accountid=1 88056. DOI: http://dx.doi.org/10.12955/cbup.v5.927.

[2] B. Z. Karimova, S. K. Alimbekova and A. D. Mukhatova, "Ecological Problems in Mass Media in Kazakhstan," Journal of Pharmaceutical Sciences and Research, vol. 10, (6), pp. 1422-1427, 2018.

Available: https://search.proquest.com/docview/2091084321 ?accountid=1 88056.

[3] C. Edu. "The Aral Sea Crisis." columbia.edu http://www.columbia.edu/ tmt2120/impacts $\% 20$ to $\% 201$ ife $\% 20$ in\%20the\%20region.htm (Accessed Feb. 13, 2020)

[4] C. Facts. "Caspian sea facts." caspinfo.net. http://www.caspinfo.net/content/content.asp?menu=0120000_0 00000 (Accessed Feb. 11, 2020)

[5] D. Arystambekova, J. Daulet, S. Aizhan, K. Gulnar, and M. Kulash, "Assessment of Changes in the Maximum Flow of Kazakhstan Plain Rivers." Journal of Ecological Engineering 20, no. 5 (2019). DOI: http://dx.doi.org/10.12911\%2F22998993\%2F105633.

[6] E. Krupa et al, "STATISTICAL MAPPING AND 3-D SURFACE PLOTS IN PHYTOPLANKTON ANALYSIS OF THE BALKHASH LAKE (KAZAKHSTAN)," Transylvanian Review of Systematical and Ecological Research, vol. 20, (1), pp. 1-16, 2018. Available: https://search.proquest.com/docview/1965579488? accountid=1 88056. DOI: http://dx.doi.org/10.1515/trser-2018-0001.

[7] G. D. Amanova et al, "State and Challenges of Environmental Accounting in the Republic of Kazakhstan," Journal of Environmental Management \& Tourism, vol. 8, (1), pp. 155-167, 2017. Available: https://search.proquest.com/docview/1936485936?accountid=1 88056. DOI: http://dx.doi.org/10.14505/jemt.v8.1(17).16.

[8] G. Issanova et al, "Dust storms in Kazakhstan: Frequency and division," Journal of the Geological Society of India, vol. 85, (3), pp. 348-358, $2015 . \quad$ Available: https://search.proquest.com/docview/1691983683? accountid=1 88056. DOI: http://dx.doi.org/10.1007/s12594-015-0224-5.

[9] G. Issanova et al, "Water availability and state of water resources within water-economic basins in Kazakhstan," Paddy and Water Environment, vol. 16,(1), pp. 183-191, 2018. Available:

https://search.proquest.com/docview/1994208064?accountid=1 88056. DOI: http://dx.doi.org/10.1007/s10333-018-0630-6.

[10] G. Issanova, J. Reyisha, A. Jilili, K. Azamat, S. Galymzhan, and Y. Ge. "Water availability and state of water resources within water-economic basins in Kazakhstan." Paddy and water environment 16, no. 1 (2018): 183-191. DOI: https://doi.org/10.1007/s10333-018-0630-6.

[11] I., Onyusheva, "The eco-problems and green economy development in Kazakhstan." (2018). Available: http://www.zbw.eu/econisarchiv/bitstream/handle/11159/2227/102475037X.pdf?sequenc $\mathrm{e}=1$. 
[12] K. Bennett. "Disappearance of the Aral Sea." wri.org. https://www.wri.org/blog/2008/05/disappearance-aral-sea (Accessed Feb. 13, 2020)

[13] K. Khalilova. "Caspian Sea oil boom raises pollution fears." bbc.com. https://www.bbc.com/news/10132781 (Accessed Feb. 10, 2020)

[14] K. Mukhtarova et al, "Analysis and Evaluation of Environmental Management," Journal of Environmental Management \& Tourism, vol. 9, (1), pp. 167-174, 2018. Available:

https://search.proquest.com/docview/2078758598?accountid=1 88056. DOI: http://dx.doi.org/10.14505/jemt.v9.1(25).21.

[15] K. Nature. "Environmental issues in Kazakhstan." naturvernforbundet.no https://naturvernforbundet.no/international/environmentalissues-in-kazakhstan/category936.html (Accessed Feb. 11, 2020)

[16] K. Strategy. "ENVIRONMENT ASSESSMENT (SUMMARY)." Adb.org. https://www.adb.org/sites/default/files/linked-documents/cpskaz-2012-2016-ena.pdf (Accessed 15 February, 2020).

[17] L. Igaliyeva and S. Yegemberdiyeva, "THE MECHANISM OF ECONOMIC MANAGEMENT IN THE REGIONS OF KAZAKHSTAN TO ENSURE ENVIRONMENTAL SAFETY," $C B U$ International Conference Proceedings ..., vol. 7, pp. 137-142, 2019. Available:

https://search.proquest.com/docview/2358449599?accountid=1 88056. DOI: http://dx.doi.org/10.12955/cbup.v7.1353.

[18] L. Igaliyeva and Y. Saule "The Mechanism Of Economic Management In The Regions Of Kazakhstan To Ensure Environmental Safety." In $C B U$ International Conference Proceedings, vol. 7, pp. 137-142. 2019. DOI: https://doi.org/10.12955/cbup.v7.1353

[19] S. Bayandinova, M. Zheken and I. Gulnura Man-made ecology of east Kazakhstan. Berlin: Springer, 2018.

[20] S. Report. "Senate speaker raised concern over environmental problems in Kazakhstan." The Asian Times.com. https://astanatimes.com/2019/04/senate-speakerraised-concern-over-environmental-problems-in-kazakhstan/ (Accessed 15 February, 2020).

[21] Z. Abdukarimova et al, "Features of Compensation for Damage Caused to Natural Resources in Kazakhstan," Journal of Advanced Research in Law and Economics, vol. 9, (4), pp. 1169-1175, $2018 . \quad$ Available: https://search.proquest.com/docview/2221144914?accountid=1 88056. DOI: http://dx.doi.org/10.14505/jarle.v9.4(34).01.

[22] Z. Abdukarimova et al, "Features of Compensation for Damage Caused to Natural Resources in Kazakhstan," Journal of Advanced Research in Law and Economics, vol. 9, (4), pp. 1169-1175, $2018 . \quad$ Available: https://search.proquest.com/docview/2221144914?accountid=1 88056. DOI: http://dx.doi.org/10.14505/jarle.v9.4(34).01.

[23] Z. Karbetova et al, "Strategic Priorities and Challenges of Environmental Management in Kazakhstan," Journal of Advanced Research in Law and Economics, vol. 7, (5), pp. 1058-1065, 2016.2 Available: https://search.proquest.com/docview/1980473711 ?accountid=1 88056. DOI: http://dx.doi.org/10.14505/jarle.v7.5(19).12.

\section{AUTHORS}

First Author: Kalimova Ainara, Master candidate, Tongji University, UN Environment-Tongji Institute of Environment for Sustainable Development (IESD): College of Environmental Science and Engineering: Email ainarakalimova@mail.ru: Phone No +8613127506929: Address: 1299 Siping Road, Shanghai 200092, China Second Author:Dong Bin, Mentor and Supervisor, Tongji University, UN Environment-Tongji Institute of Environment for Sustainable Development (IESD): College of Environmental Science and Engineering:Email dongbin@ tongji.edu.cn, ti_dongbin@163.com Phone No+8613918126169: Address: 1299 Siping Road, Shanghai 200092, China

Third Author: Davaasambuu Ulzii-orshikh, Master candidate, Tongji University, UN Environment-Tongji Institute of Environment for Sustainable Development (IESD): College of Environmental Science and Engineering: Email

Davaa9852@gmail.com: Phone No +8613917502603:

Address: 1299 Siping Road, Shanghai 200092, China

Correspondence Author: Kalimova Ainara, Master candidate, Tongji University, UN Environment-Tongji Institute of Environment for Sustainable Development (IESD): College of Environmental Science and Engineering: Email ainarakalimova@mail.ru: Phone No +8613127506929: Address: 1299 Siping Road, Shanghai 200092, China 